\title{
Genetic diversity of pod traits in local populations of Medicago ciliaris $\mathbf{L}$.
}

\author{
Jabri Cheima ${ }^{1}$, Zoghlami - Khelil Aziza ${ }^{2}$ Medini Maher ${ }^{3}$ Trifi- Farah Neila ${ }^{4}$ \\ ${ }^{1,3}$ Banque Nationale de Gènes. Boulevard du leader Yasser Arafat. Charguia 1. 1080 Tunis. Tunisie. \\ ${ }^{2}$ Laboratoire de Production Animale et Fourragère. Institut National de la Recherche Agronomique de Tunisie. \\ Rue Hédi Karray-2049. Ariana. Tunisie. \\ ${ }^{4}$ Laboratoire de Génétique Moléculaire, Immunologie et Biotechnologie. Faculté des Sciences de Tunis. 2092 El \\ Manar. Tunis. Tunisie.
}

\begin{abstract}
The present study estimated the genetic diversity of Tunisian populations of Medicago ciliaris L. by assessing nine morphological pod traits among 14 local populations conserved at the National Gene Bank of Tunisia. Pod diameter and pod weight were the most discriminating variables and were significantly correlated. According to Nei statistical analyses, mean genetic diversity $\left(H_{T}\right)$ for all traits recorded across all populations averaged 0.300 and ranged from 0.438 for pod shape to 0.204 for angle of insertion of spines. High genetic differentiation among populations $\left(G_{S T}=0.213\right)$ for all traits and particularly for qualitative ones $\left(G_{S T}=0.324\right)$ was found. Angle of insertion of spine displayed a little genetic variation among populations $\left(H_{T}=0.204\right)$ while pod shape displayed a high level of genetic variation $\left(H_{T}=0.349\right)$. It appears that pod characters are useful tools for a preliminary investigation of genetic diversity of Medicago ciliaris L. populations. These traits helped us to differentiate the population from Dougga as an ecotype.
\end{abstract}

Key-words: Medicago ciliaris L.; pods morphology, genetic diversity; local populations.

\section{Introduction}

Genetic variation between and within populations is considered as a result of the environmental heterogeneity and the action of natural selection [1]. Information on genetic diversity available within and among natural populations of annual Medicago species is poorly documented [2].

Medicago ciliaris $\mathrm{L}$. is a diploid species $(2 \mathrm{n}=16)$ belonging to the Section of Spirocarpos subsection of Intertextae as delimited by Heyn, [3]. It is predominantly selfing annual plant of the Mediterranean region, [4]; [5]. Although this subsection is well demarcated from all other subsection of genus Medicago, species relationships within it have been controversial, [6]. The fruit of genus Medicago, recognized as a pod, is the most characteristic part of the plant. It is also the organ of propagation of the species, [3]; [7]. Almost half of species of this genus can be identified based only on their morphologic pod appearance [8]. Difficulties in the identification and the classification of this genus are primarily due to the considerable variation in vegetative and pod characters, and to the occurrence of intermediate forms [9].

This paper is the first dealing with phenotypic and genetic pod diversity of local populations of Medicago ciliaris L. in Tunisia. It aimed to (a) explore significant variation in pod morphological traits and (b) estimate genetic variation based on pod traits.

\section{Materials and methods}

Fourteen local populations of Medicago ciliaris L. conserved at the National Genes Bank of Tunisia were used in this study. These populations were collected from different regions in northern and central Tunisia (Fig 1). The main characteristics of their origin sites are presented in Table 1.

Data were recorded for qualitative and quantitative traits using the international norms of IBPGR [10], UPOV, [11] and criteria of Fawzy [12] concerning the genus Medicago (Table 2). These parameters were measured on each pod individually on a sample of 25 pods taken randomly from each population. Phenotypic frequency distributions of the characters were calculated for all populations. For quantitative data, analysis of variance with one factor of classification (population) was performed using the SAS Software [13].

For genetic diversity analysis, frequencies data for each quantitative and qualitative trait and population were used to calculate the following statistics according to Nei, [14]; [15: gene diversity for each phenotypic marker $(H)$; mean number of alleles per locus; effective number of phenotypic markers per locus; percent of polymorphic loci; total gene diversity $\left(H_{\mathrm{T}}\right)$ and genetic differentiation $\left(G_{S T}\right)$. Statistical analysis was conducted using POPGENE 1.32 software [16]. 


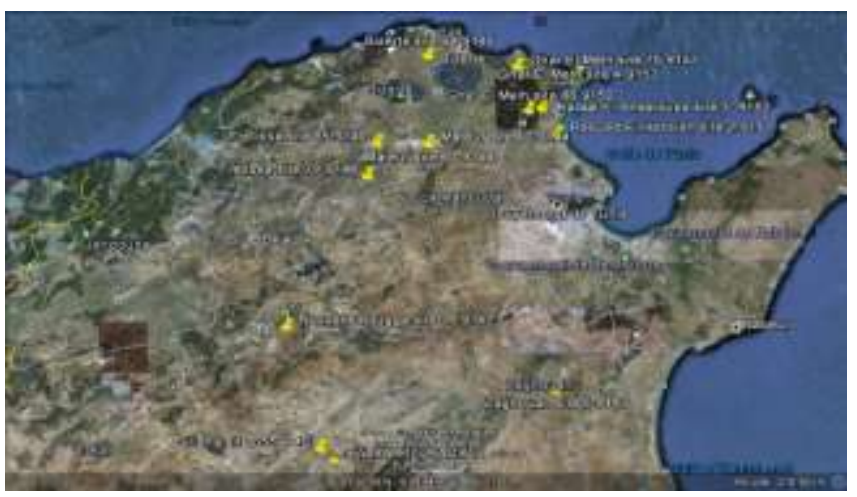

Figure. 1. Collection sites of the fourteen populations of M. ciliaris L. populations in Tunisia

Table1. The main characteristics of the collection sites of Medicago ciliaris populations L.

\begin{tabular}{llllllll}
\hline $\begin{array}{l}\text { Populations } \\
\text { code }\end{array}$ & Site Name & Provence & $\begin{array}{l}\text { Year of } \\
\text { collection }\end{array}$ & $\begin{array}{l}\text { Altitude } \\
(\mathrm{m})\end{array}$ & $\begin{array}{l}\text { Rainfall } \\
(\mathrm{mm})\end{array}$ & $\begin{array}{l}\text { T Max } \\
\left({ }^{\circ} \mathrm{C}\right) *\end{array}$ & $\begin{array}{l}\text { T Min } \\
\left({ }^{\circ} \mathrm{C}\right) *\end{array}$ \\
\hline 9140 & Siliana & Siliana & 1992 & 575 & 341.1 & 38.6 & 1.6 \\
9141 & Oued Messouge & Siliana & 1992 & 500 & 367.1 & 38.6 & 1.6 \\
9142 & Dougga & Teboursouk & 1992 & 320 & 493.5 & 21.7 & 9.9 \\
9143 & Zaghouan & Zaghouan & 1994 & 300 & 496.0 & 32.6 & 6.7 \\
9144 & Mateur 1 & Mateur & 1994 & 5.00 & 527.1 & 33.4 & 4.9 \\
9145 & Bizerte & Bizerte & 1994 & 5.00 & 554.2 & 31.8 & 6.7 \\
9146 & Fretissa 1 & Mateur & 1994 & 125 & 581.1 & 33.4 & 4.9 \\
9147 & Ghar El Melh 2 & Bizerte & 1994 & 150 & 507.4 & 31.1 & 7.6 \\
9148 & Frétissa 2 & Mateur & 1994 & 240 & 582.0 & 33.4 & 4.9 \\
9149 & Mateur 2 & Mateur & 1994 & 10.0 & 527.1 & 33.4 & 4.9 \\
9150 & Ghar El Melh 1 & Bizerte & 1994 & 10.0 & 507.0 & 31.8 & 6.7 \\
9151 & Raoued El hessiane & Ariana & 2009 & 5.75 & 398.5 & 35.1 & 5.4 \\
9152 & Kalaat Andalous & Ariana & 2009 & 5.85 & 398.5 & 35.1 & 5.4 \\
9153 & Ghar El Melh 3 & Bizerte & 2009 & 6.19 & 497.8 & 32.9 & 6.7 \\
\hline
\end{tabular}

*: Tmax: average maximum temperature, Tmin: average minimum temperature.

Table 2. Qualitative and quantitative parameters scored on pods of the fourteen populations of Medicago

\begin{tabular}{|c|c|c|}
\hline Qualitative parameters & Code & Scale \\
\hline Hairiness of the pod & PH & $\begin{array}{l}\text { According to } 1-5 \text { scale of Fawzy-Ahmed \& Atia (1994) } \\
: 1=\text { glabrous; } 2=\text { sparsely hairy; } 3=\text { moderately hairy; } 4=\text { densely } \\
\text { hairy; } 5=\text { woolly canescent }\end{array}$ \\
\hline Pod shape & PS & According to 2 - 3 scale of UPOV (2006): $2=$ spherical; $3=$ ovoid \\
\hline Spine length * & SL & According to 3 - 4 scale of IBPGR (1991): $3=$ short; $4=$ long \\
\hline $\begin{array}{l}\text { Angle of insertion of the } \\
\text { spine* }^{*}\end{array}$ & AIS & $\begin{array}{l}\text { According to } 2-4 \text { scale of IBPGRI }(1991): 2=90^{\circ} ; 3=90 \text { to } 180^{\circ} ; \\
4=180^{\circ}\end{array}$ \\
\hline Quantitative parameters & Code & Unit \\
\hline Number of seeds per pod & SN & $m g$ \\
\hline Number of coils per pod & $\mathrm{NC}$ & number \\
\hline Pod height & $\mathrm{H}$ & $m m$ \\
\hline Pod diameter & $\mathrm{D}$ & $m m$ \\
\hline Pod weight & PW & $m g$ \\
\hline 100 seeds weight & HSW & $m g$ \\
\hline
\end{tabular}

*: SL and AIS are quantitative traits but not measurable; so they were classified into categories and considered as qualitative traits.

\section{1, Analysis of variance}

\section{Results and discussion}

Analysis of variance applied on quantitative traits showed a high significant effect of population $(\mathrm{P}<$ $0.0001)$ for all characters except seeds number $(\mathrm{P}>0.05)$. Pod diameter and pod weight were the most significant 
variables $(\mathrm{P}<0.0001)$. This result is partially in agreement with that reported by Heyn, [3]. This author mentioned that the distinction between varieties of section Intertextea of genus Medicago was based mainly on pod morphology. However, according to Fawzy [12], the occurrence of intermediate forms and the considerable variation in pod characters make difficult the identification and classification of the genus Medicago. Variability in pod characters like height, width and number of coils was large among Sicilian populations of Medicago truncatula [17].

Significant correlations were observed between pod weight and pod height $(\mathrm{r}=0.67, \mathrm{P}<0.0001)$, pod diameter and seed weight $(r=0.72, \mathrm{P}<0.0001)$ and between pod and seed weight $(\mathrm{r}=0.771, \mathrm{P}<0.05)$. This result is on line with that of Graziano, [17] who reported that pod size was directly related to seed weight, and genotypes with small seeds produced more seeds per unit area. It may be an advantage to have more small seedlings than fewer large seedlings in environments where the risk of seedling death is high [18]; [19].

\section{2, Phenotypic diversity analyses}

Average gene diversity $(H)$, mean number of polymorphic loci and percent of polymorphic loci for all populations were respectively, $0.23,20.28$ and 82.92 (Table 3). Genetic diversity varied from 0.17 for population 9142 (from Dougga) to 0.28 for population 9147 (from Ghar El Melh). The lowest genetic diversity observed within the population 1942 from Dougga could be explained by the fact that it was collected in a protected area (Roman ruins) and this suggested that this population was isolated for a long period of time. While the highest value observed in population 9147 (from Ghar El Melh) could be related to its environmental conditions (salty area near sea of Ghar El Melh).

Gene diversity was positively and significantly correlated with number and percent of polymorphic loci $(\mathrm{r}=0.872 ; \mathrm{P}<0.0001$ for each). The mean number of alleles per locus was positively and significantly correlated with percent of polymorphic loci $(\mathrm{r}=0.892 ; \mathrm{P}<0.0001)$.

Table 3. Gene diversity $(H)$, mean number of alleles per locus, number and percent of polymorphic loci for nine quantitative and qualitative traits within fourteen local populations of $M$. ciliaris $\mathrm{L}$.

\begin{tabular}{lcccc}
\hline Populations & $H$ & $\begin{array}{c}\text { Mean number of alleles } \\
\text { per locus }\end{array}$ & $\begin{array}{c}\text { Number of polymorphic } \\
\text { loci }\end{array}$ & $\begin{array}{c}\text { Percentage of } \\
\text { polymorphic loci }\end{array}$ \\
\hline 9140 & 0.214 & 1.76 & 19 & 76 \\
9141 & 0.210 & 1.76 & 19 & 76 \\
9142 & 0.176 & 1.60 & 15 & 60 \\
9143 & 0.258 & 1.88 & 22 & 88 \\
9144 & 0.248 & 1.92 & 23 & 92 \\
9145 & 0.252 & 1.88 & 22 & 88 \\
9146 & 0.230 & 1.72 & 18 & 72 \\
9147 & 0.286 & 1.92 & 23 & 92 \\
9148 & 0.217 & 1.76 & 19 & 96 \\
9149 & 0.278 & 1.96 & 24 & 84 \\
9150 & 0.232 & 1.84 & 21 & 92 \\
9151 & 0.269 & 1.92 & 23 & 84 \\
9152 & 0.262 & 1.84 & 21 & 68 \\
9153 & 0.213 & 1.68 & 17 & 82.929 \\
Mean & 0.239 & 1.82 & 20.286 & \\
\hline
\end{tabular}

\section{3, Total genetic variation and genetic differentiation}

Mean genetic diversity $\left(H_{\mathrm{T}}\right)$ for nine quantitative and qualitative traits across all populations averaged 0.300 and ranged from 0.438 for pod shape to 0.204 for angle of insertion of spines (Table 4). The extent of differentiation between populations for these traits is reflected by the correspondent $G_{S T}$ value $(0.21)$. This implies that on average $79 \%$ of the total variation is partitioned within populations (with a minimum of $52.1 \%$ for the angle of insertion of spines and a maximum of $97.5 \%$ for the seed number).

The genetic differentiation among populations of M. ciliaris $\left(G_{S T}=0.213\right)$ found to be high for all traits and particularly for qualitative ones (0.324) (Table 4). This result is not conform with that reported by Badri [2], who founded low differentiation at quantitative traits in four M. ciliaris populations. According to these authors, this may be explained by the restricted geographical distribution of M. ciliaris in Tunisia. While, high level of quantitative and molecular genetics differentiation was found among natural populations of $M$. truncatula growing spontaneously in the same areas as those of M. ciliaris [20]. According these authors, M. truncatula is a widespread species in Tunisia while M. ciliaris is limited to the north of the country. Accordingly, geographical range has been shown to be a good predictor of the levels of genetic variation in plants [21].

Al-Nashash, [22], considers that qualitative variation is less limited by natural selection than quantitative one which is highly affected by selection and environment and affects survival and production. Although Medicago. ciliaris is a self fertilizing species, a high genetic differentiation was found within 
populations $(0.79 \%)$ and ranged from a minimum of $52.1 \%$ for angle of insertion of the spines and a maximum of $97.5 \%$ for seed number. This result is not conform with that of Charlesworth, [23], who reported that selffertilizing species tend to have lower within-population and higher among-population genetic variation than outcrossing ones.

For species distribution and survival, Lesins [4], consider the spines as a mean of anchoring the pods on the spot, rather than a mean of transportation by furred animals. Pod shape displayed a high level of genetic diversity $\left(H_{\mathrm{T}}=0.349\right)$ across all populations (Table 4). Same result was found in Algerian populations of Medicago ciliaris, [24], and in twenty local cultivars of soybean [25]. This later reported that pod shape can be used as a qualitative marker to identify and classify varieties.

Table. 4. Total genetic diversity $\left(H_{T}\right)$, mean genetic diversity within populations $\left(H_{S}\right)$ and genetic differentiation $\left(G_{S T}\right)$ for five quantitative and four qualitative traits among and within the fourteen $M$. ciliaris L. populations.

\begin{tabular}{lcccc}
\hline Locus & Sample size & $H_{T}$ & $H_{S}$ & $G_{S T}$ \\
\hline Quantitative traits & & & & \\
H & 350 & 0.312 & 0.277 & 0.112 \\
D & 350 & 0.306 & 0.245 & 0.198 \\
NC & 350 & 0.300 & 0.275 & 0.083 \\
PW & 350 & 0.306 & 0.243 & 0.206 \\
SN & 350 & 0.300 & 0.292 & 0.025 \\
Mean & 350 & 0.305 & 0.266 & 0.125 \\
Qualitative traits & & & & \\
AIS & 350 & 0.204 & 0.106 & 0.479 \\
SL & 350 & 0.243 & 0.160 & 0.339 \\
PS & 350 & 0.438 & 0.346 & 0.210 \\
PH & 350 & 0.293 & 0.215 & 0.267 \\
Mean & 350 & 0.294 & 0.207 & 0.324 \\
Total mean & 350 & 0.300 & 0.240 & 0.213 \\
\hline
\end{tabular}

\section{4, Cluster Analysis}

Cluster analysis based on Nei's genetic distance was found to separate the populations into four clusters at a mean distance of 0.23 (data not shown): cluster 4 included population 9142 (the most distant one), cluster 3 included population 9151, cluster 2 linked population 9144 to 9145 and cluster 1 included the rest of populations. It can be divided into two sub clusters: sub cluster 1 with three populations $(9141,9146$ and 9148$)$ and sub cluster 2 with seven populations $(9153,9150,9140,9149,9147,9143$ and 9152) (Fig 2).

According to the amount of variation on pod morphology, population from Dougga (9142) was clearly separated from the rest of populations. It was distinguishable by the smallest pod size and the shortest spines which are inserted at angle of $90^{\circ}$. In other study, variation in karyotype for chromosome length and centromere position was found between populations of Medicago ciliaris L., [26]. It seemed that population from Dougga is the primitive one because of is medium karyotype as revealed by Shlarbum, [27], and could be could be considered as an ecotype. According to Badri [2], pods separated by short distances are more likely to be genetically related than those that are farther apart. Nevertheless, the clustering of populations based on Nei genetic distance revealed that some populations geographically distant are genetically similar (case of 9143 and 9152) while some others growing very closely (case of 9152 and 9153) were found to be genetically different.

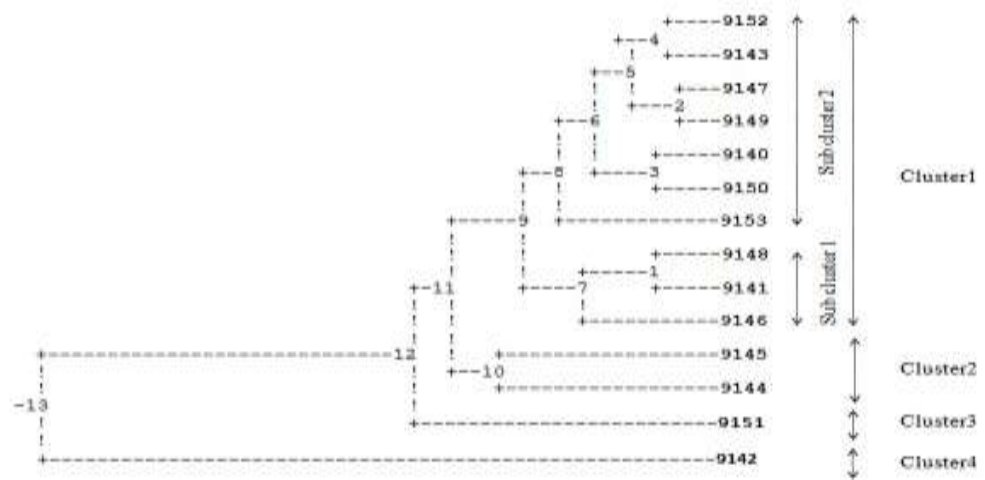

Figure. 2. Dendrogramme of Medicago ciliaris L. populations clustered based on Nei's (1978) genetic distance: Method = UPGMA 


\section{Conclusion}

The present study demonstrated the usefulness of pod characters to evaluate the genetic diversity of local M. ciliaris L. populations. Nevertheless, further molecular characterization associated with ecological data of this species could be very promising.

\section{References}

[1] P.W. Hedrick, M.E. Ginevan, E.P. Ewing, Genetic polymorphism in heterogeneous environments. The Annual Review of Ecology, Evolution, and Systematics 7, 1976, 1-32.

[2] M. Badri, A. Zitoun, H. Ilahi, T. Huguet and M. E .Aouani, Morphological and microsatellite diversity associated with ecological factors in natural populations of Medicago laciniata Mill. (Fabaceae). Journal of Genetics 87, 2008, 241-255.

[3] C. C. Heyn, The annual species of Medicago Scipta hierosly mitana (125), 1963, 131p.

[4] K. A. Lesins, and I. Lesins, Genus Medicago (Leguminosae). A taxogenetic study. W Junk Publishers: The Hague, Boston, London (1979).

[5] A. Abdelkefi, M. Boussaïd, A. Biborchi, A. Haddioui, A. Salhi-Hanachi, M. Marrakchi, Genetic diversity and valuation of spontaneous species belonging to Medicago L. Genus in Tunisia. CIHEAM-IAMZ, 143-149 p. Cahiers Options Méditerranéennes , 18 In Genier G. (Ed), Prosperi J.M. (Ed) 1996.

[6] E. Small, and M. Jomphe, A synopsis of the genus Medicago (Leguminosae). Canadian Journal of Botany 67,1989, $3260-3294$.

[7] G. Pottier-Alapetite, Flore de la Tunisie. Angiospermes-Dicotylédones. Apétales-Dialypétales 1979. 649p. 2ème partie. Edition Imprimerie Officielle de la République Tunisienne.

[8] K. Lesins and C. B. Gillies, Taxonomy and Cytogenetics of Medicago.. Reprinted from Alfalfa Science \& technology 1972 Chapter 3. pp 53-86. Monograph 15. American society of agronomy.

[9] M. F. Ahmed, A study of the cyto-taxonomy for conservation of genetic resources for forage legumes (Medicago species) in Omayed Bisophere reserve. Egypt, 1994. 135 pp. 8pls. 5 annexes.

[10] IBPGR, Descriptors lists for annual Medicago. International Board for Plant Genetic Resources. (Via dell sette. 142. Rome (Italy), 1991, 33p).

[11] UPOV, Luzernes annuelles: principes directeurs pour la conduite de l'examen de la distinction de l'homogénéité et de la stabilité. (TG/228/1 du 05/04/2006,1-26).

[12] M. F. Ahmed and W. K. Atia, Taxonomical studies on the genus Medicago in Egypt. Journal of King Saud University. Vol.6. Science 2, 1994, 167-180.

[13] SAS, Guide for personnel computers Institute, Inc, SAS - STATTM, (6th Eds, 1998, 534p).

[14] E. Nei, Analysis of gene diversity in subdivided populations. Proceedings of the National Academy of Sciences. (USA) 70, 1973, 3321-3323.

[15] E. Nei, Estimation of average heterozygosity and genetic distance from a small number of individuals. Genetics 89, 1978, 583-590.

[16] F. C. Yeh, R.C. Yang, and T. B. J. Boyle, Z. H. Ye and J. X. Mao, POPGENE, the user-friendly shareware for population genetic analysis. Molecular Biology and Biotechnology Center, University. of Alberta, Edmonton Alberta, Canada, 1997.

[17] D. Graziano, , G. Di Giorgio, P. Ruisi, G. Amato, D. Giambalvo, Variation in pheno-morphological and agronomic traits among burr medic (Medicago polymorpha L.) populations collected in Sicily, Italy. Crop \& Pasture Science 61, 2010, 59-69.

[18] P.S. Cocks, Dynamics of flower and pod production in annual medics (Medicago spp.), I. in spaced plants. Australian Journal of Agricultural Research 41, 1990, 911-921.

[19] P.S. Cocks, Plant attributes leading to persistence in grazed annual medics (Medicago spp.) growing in rotation with wheat. Australian Journal of Agricultural Research, 43,1992, 1559-1570.

[20] M. Badri, K. Zribi, S, Soula, F. Lazrek, Y. Badri, M. Khaldi, N. Yousfi, N. Djebali, T. Huguet, M.E. Aouani, Specificities and usefulness of medics-sinorhizobia symbioses in Tunisian areas: preliminary assessment of the statement. In: Abstracts of the 5 th Tunisian-Japanese on Culture, Science and Technology, Sfax, Tunisia, 2004.

[21] M. A. Gitzendanner and P.S. Soltis, Patterns of genetic variation in rare and widespread plant congeners. American Journal of Botany, 87, 2000, 783-792.

[22] A. Al-Nashash, M. Migdadi, M. A. Shatnawi, H. Saoub, S. Masoud, Assessment of Phenotypic Diversity among Jordanian Barley Landraces (Hordeum vulgare L.). Biotechnology 6, (2), 2007, 232-238.

[23] D. Charlesworth, Effects of inbreeding on the genetic diversity of populations. Philosophical Transactions of the Royal Society B: Biological Sciences, 358, 2003, 1051-1570.

[24] H. E. Khelifi, M. Abdelguerfi, M. M. Bouzina, D. Bellague, A. Chedjerat, K. Abbas, T. Huguet, M. E. Aouani, A. Abdelguerfi, Diversité des marques foliaires et des formes de gousses chez trente-neuf populations algériennes de Medicago ciliaris et de Medicago intertexta. In diversity of fodder Fabaceae and their Symbionts: "Biotechnological, Agronomic and Environmental Applications", Inernationnal Workshop,19-22 February, 2006, Algeries. 48- 86.

[25] N. T. Truong, J.G. Gwag, Y. J. Park, and S. H. Lee, Genetic Diversity of Soybean Pod Shape Based on Elliptic Fourier Descriptors. Korean Journal of Crop Science. 50,2005, (1).

[26] C. Jabri, E. Abassi, A. Zoghlami, N. Trifi, Etude morphologique et caryologique de trois populations de Medicago ciliaris L. XXème journées Nationales de Biologie de la SSNT" Biologie et Qualité de la Vie" du 04 au 07 Novembre 2010 à Yasmine Hammet, Tunisie.

[27] S. E. Schlarbaum, E. Small, B. L. Johnson, Karyotypic Evolution, morphological variability and phylogeny in Medicago sect Intertextae Plant systematic and evolution. 145,1984, 203-222. 